\title{
Course Strategy: Low Stakes Assessment Approach to Engineering Economy instruction using Revised Bloom Taxonomy
}

\section{Mr. Michael B. O’Connor P.E., New York University}

Michael O'Connor, Retired Professional Civil Engineer (Maryland and California), M.ASCE, is a member of the ASCE Committee on Developing Leaders, History and Heritage, Civil Engineering Body of Knowledge (CEBoK), and Engineering Grades. Michael has been a practicing Civil Engineer with over 50 years of engineering, construction, and project management experience split equally between the public and private sectors. Programs ranged from the San Francisco Bay Area Rapid Transit district's 1990's expansions in the East Bay and SFO Airport at three billion to the New Starts program for the Federal Transit Administration with over a hundred projects and $\$ 85$ billion in construction value. At the latter, he also acted as source selection board chairman and program COTR for \$200 plus million in task order contracts for engineering services. Working for the third-largest transit agency in the United States, the Los Angeles County MTA, Michael managed bus vehicle engineering for $\$ 1$ billion in new acquisitions and post-delivery maintenance support for 2300 vehicles with some of the most complex technology (natural gas engines and embedded systems) in the US transit industry in the 1990s. Michael also has extensive experience as an instructor at New York University (five years), Howard University (four years), and California State University- San Francisco (ten years). 


\section{Low Stakes Assessment Approach to Engineering Economy Instruction using revised Bloom Taxonomy}

\section{Disclaimer}

The author has had various affiliations within the American Society Of Civil Engineers and its committees, including work on the Civil Engineering Body of Knowledge Committee for the third edition. Specifically, the technical outcomes and rationale for engineering economics. The observations, conclusions, and recommendations in this paper are those of the author and not necessarily of the ASCE.

\section{Instructional Environment}

The Civil and Environmental Engineering Department at Howard University in Washington, D.C., manages a BS in Civil engineering (BSCE) program with a population average of 75 students. Howard's enrollment is approximately 9,700 undergraduate, graduate, and professional students. The engineering economics course is an undergraduate offering offered only once per year in the spring semester. Its size varies from 15 to 25 students, primarily juniors. The only pre-requisite is probability and statistics. The class is also offered to other College of Engineering and Architecture disciplines, mechanical and chemical engineering.

\section{Delivery Method}

The author started instruction for the course in 2018 using the traditional classroom lecture method using the learning management system (LMS) "Blackboard" (Bb). However, the assessment approaches and lessons learned apply to other LMSs. The course migrated to a hybrid delivery in 2019. The LMS and video conferencing (Zoom) technology facilitated the migration in delivery methods. This trend continued, and the course went entirely online in the Spring of 2020 with the onset of the Covid-19 pandemic. During this period in 2020, the author became aware of the "flipped classroom" delivery method. [14] The syllabus was reworked to move the lecture material out of the classroom into video presentations ranging in length from 10 to 45 minutes. [13] Each module was standardized around pre-class reading, videos, practice quiz sets, and a pre-class quiz. The out-of-class material was screened using the Bloom taxonomy to limit the associated cognitive levels to remember, comprehend, and apply, as discussed below. The class sessions were recorded and then edited using Adobe Premiere Rush video editing software mainly to eliminate dead spells and sped the play rate to $125 \%$ of the original. Breaks in the material were flagged with PowerPoint slides to allow the students to manually select portions of the video to watch relevant to them. This reduced playtime on average from 90 minutes to 40 minutes. At the end of each week, an online assignment incorporated all the material for the module and is discussed further below. Also, the students reflected on their experience and learning attainment in a weekly journal submission. An end-ofsemester survey used a Likert scale, focusing on their perceived ability to solve complex problems in engineering economics. As of 2021, the course was asynchronous, with several students unable to participate in the lectures either due to other class conflicts or time-zone issues. At the end of the semester, 25 hours of edited class video had been produced, with another 15 hours of associated pre-class videos also produced. 


\section{Low Stakes Assessment Approach to Engineering Economy Instruction using revised Bloom Taxonomy}

\section{Future Concerns and Challenges}

The University has not decided as of the time of this paper (May 2021) when it will return to inperson instruction. However, it seems likely that in the spring of 2022, the course will be given in person. The production of forty hours of video materials for the class was an enormous investment of time and effort. This class was only one of a number across the country that had to develop these materials. The challenge is to decide how they to be used going forward. This paper recommends that this material and others at other schools be reviewed for best practices and value. These materials would then ideally be available from the ASEE Engineering Economics division on a non-commercial basis. Individual instructors would be able to share these materials and tailor them to their specific program needs. This Instructor plans to continue with the "flipped classroom" delivery method. The challenge in this would be to incorporate more formal communication and teamwork scope into the course. The formal communication would be in the form of engineering economic deliverables and teamwork in collaborative learning exercises. [10]

\section{Approach to Instruction and Technology}

The course was redesigned in 2018 to use a problem-based learning (PBL) process that allowed the Instructor to meet program-specific learning outcomes such as Accreditation Board for Engineering and Technology (ABET) and discipline-specific objectives. Problem-based learning has been defined as "an instructional method where student learning occurs in the context of solving an authentic problem."[12] The method has found "widespread use in engineering ...curriculums" [11]. The problem-based learning (PBL) model for this course integrates mathematics, economics, accounting, finance, communications, project management, and engineering technology instruction around a core of industry-related problems. [10] A unique aspect of this method is the use of curriculum materials to simulate professional practice and workplace scenarios. [11] The course material notes that civil engineering (CE) problems require students to grasp two aspects of CE practice, theory and procedure. A student may understand the theory behind an application like economic equivalence, standard costing, or learning curves but applying that theoretical knowledge to solving a problem requires procedural knowledge. [1] Spreadsheets expose the students to the procedural applications of CE theory to solve practical problems. Understanding both the problem and how to solve a problem are critical skills in professional practice. The problem sets are complex and open-ended, containing misleading information and ambiguities. They cannot be solved in a single step and require multiple attempts to become adept at their solution using spreadsheet software. [15] 


\section{Low Stakes Assessment Approach to Engineering Economy Instruction using revised Bloom Taxonomy}

\section{Technology}

In addition to spreadsheet technology, the course uses the learning management system (LMS) software "Blackboard" (Bb). Although the assessment approaches and lessons learned apply to other LMSs. All of the (1) reference information such as syllabus, work plans, (2) reading materials, and (3) content inclusive of assessments were on the LMS. Other software such as Logitech, Zoom, and Adobe capture was used to create the video materials. Adobe Premiere Rush was used to edit the raw video materials into finished products.

\section{Challenges}

The primary challenge in the class is to facilitate student learning using "scaffolding" to allow them to move from Understand/Comprehend thru Apply/Execute to Apply/Implement.

Scaffolding has been defined as "providing supports that allow students to complete tasks they would not otherwise be able to complete successfully." [22] Brockway argued that scaffolding allows an instructor to understand the student's ability to solve complex problems fully. Limiting the scope of the assessment component (true/false, multiple-choice, calculated numeric, calculated formula) or reducing the degrees of freedom are typical approaches. Students are challenged in solving complex problems by first translating word problems to math models, identifying appropriate variables/constants, and lastly, choosing and manipulating the appropriate mathematical model. The Instructor was working with a class trying to get the students over the proverbial wall of confusion in solving a problem when a student expressed in exasperation that they could not even begin to see the variables in the problem, let alone a model. The Revised Taxonomy can assist in developing a scaffolded approach to complex problems to reduce student anxiety and frustration:

- Comprehend- (Interpret): Interpreting occurs when a student is able to convert the information in the form of a word problem from one representational form to another; i.e., words to numbers. The LMS offers the student multiple-choice or True/False questions that take a multi-paragraph problem and break it down into component topics and associated models. A three-paragraph word problem may have the first be an uncertainty computation, the second a location adjustment, and the third a real/nominal value calculation.

- Comprehend- (Pre-Modeling): Interpretations may be in the form of a schematic or premodeling step. Again, the LMS offers the student multiple-choice or True/False questions that take a multi-paragraph problem and ask the student to identify variable relationships, constants, and logic tests in information. This is done to scaffold their ability to identify algebraic expressions in the problem to carry out procedures using developed models.

- Apply-(Execute) Carry out or use a procedure in a given situation and familiar context without the need to manipulate the algebraic expression, adjust parameters or variables. The students solve these types of problems before the more difficult Implement type. 


\section{Low Stakes Assessment Approach to Engineering Economy Instruction using revised Bloom Taxonomy}

The secondary challenge is to convince the students that, unlike their other coursework, the problem sets in this class will quickly exceed the capability of the student to solve using hand calculators or, worse, their smartphones. For this course, the LMS is configured using the calculated formula function to generate 100 to 250 datasets per problem, with multiple attempts allowed to solve the problem. Based on this information, the student must capture each attempt's results to diagnose the cause of what the system tells them is an incorrect response. This is not something that can be done with a hand calculator or smartphone. From a professional practice perspective, the young engineer undergoes rigorous scrutiny when presenting a solution to their manager. The key is to instill confidence in the manager that the aspiring professional used due diligence in developing the answer. The primary element in this process is the ability of the aspiring professional to recreate their work and logic in answering the question or producing the solution. For the most part, this can only be accomplished with spreadsheet products. The course requires the students to build a solutions template using spreadsheet technology such a Microsoft Excel or Google Sheets that documents the student's attempts to solve the problem and run diagnostics on their results.

\section{Academic Integrity}

Research has indicated that PBL is a vital feature of academic integrity in an online environment. [15] [16] For this course, the LMS was configured using the calculated formula function to generate 100 to 250 datasets per problem. Problems were designed to be augmented with supplemental answers that described the student's solution approach and spreadsheet templates in solving the problem. Some students submitted explanations for problems the LMS had not given them or presented spreadsheet solutions for problems with the wrong parameters. The course took full advantage of the LMS features to track student access and times to take quizzes and assignments. This method required setting up the course in the LMS to track statistics to help identify potential collusion.

\section{Topics Covered}

The topics for the class came from the Civil Engineering Body of Knowledge, $3^{\text {rd }}$ ed. (CEBoK3) [17] and the Engineering Competency Model developed by the US Department of Labor in 2017. [18] [19] With the publication of the CEBoK3 in 2019, engineering economics was added as a technical outcome increasing its emphasis for preparing future civil engineers. The CEBoK3 noted that

"The term engineering economics may be slightly misleading because it really involves more than economics for engineering. Engineering economics is more comprehensive and is the traditional and common term used for the application of both business and economics to engineering projects." Civil Engineering Body of Knowledge, $3^{\text {rd }}$. ed. In addition to the classical concepts and principles of engineering economics, such as time value of money and interest rates, added several discipline-specific topics related to project delivery, noting that "(e)ngineering economics is a critical component of project management and 


\section{Low Stakes Assessment Approach to Engineering Economy Instruction using revised Bloom Taxonomy}

incorporates concepts of risk and uncertainty." [17] The CEBoK3 went on to note that "all civil engineers should understand that project decisions have broad economic implications, and they must be able to estimate these impacts." [17] The CEBoK3 and the Engineering Competency Model (ECM) overlapped in engineering economics and complimented each other. The ECM listed engineering economics as a tier 4 Industry-wide competency (4.8) [18]. It included several topics other than the traditional time value of money and listed five specific outcomes.

- (4.8.1) Prepare detailed cost estimates of capital and annual operating costs, maintenance and repair, and replacement costs for a project or component of a project, such as equipment, materials, assembly, inspection, modification, quality assurance, etc.

- (4.8.2) Calculate the return on investment, present worth, and/or annual cost and benefit of a project having initial capital and annual operation, maintenance, repair, salvage value, and replacement costs using appropriate interest, discount, and projected inflation rates.

- (4.8.3) Identify and quantify the economic risks associated with a project or product, including how warranty costs are considered for a product.

- (4.8.4) Compare design alternatives with varying cost profiles on a present worth or annual cost basis.

- (4.8.5) Interact with managers and other professionals to provide project economic information and opinions of project costs in financial analysis and financing.

Key areas of interest for the civil engineering profession would be the preparation of detailed cost estimates for projects (4.8.1), estimated benefit-costs for the project and developing estimates of project inflation (4.8.2), the identification and quantification of cost and schedule risk for the project (4.8.3), developing economic analyses for design alternatives and project delivery methods (4.8.4), developing economic analyses of contractual pricing/costing such as in procurement actions for award and disputes (construction claims). (4.8.5) Other elements of engineering economics were in the Business, Legal, and Public Policy section (4.6), such as

- Overhead, profit, direct and indirect labor, cost, revenue

- Contracts, costing approaches, fee structures

- Cost and pricing of products

- Fundamentals of accounting [18]

The course differentiated between topics in conceptual knowledge and those of procedural knowledge as outlined in the revised Bloom taxonomy [1] and as recommended by Everett (1999). [20] 


\section{Low Stakes Assessment Approach to Engineering Economy \\ Instruction using revised Bloom Taxonomy}

\section{Conceptual Knowledge Topics}

The course covers the following topic areas:

\begin{tabular}{|c|c|c|c|c|}
\hline Module & \multicolumn{3}{|c|}{ Source } & Content \\
\hline $\begin{array}{l}\text { Socio-economic } \\
\text { context }\end{array}$ & \multicolumn{3}{|c|}{$\begin{array}{l}\text { Civil Engineering Body } \\
\text { of Knowledge, } 3^{\text {rd }} \text {. } \\
(\mathrm{CEB} \text { oK } 3)\end{array}$} & $\begin{array}{l}\text { The economics of civil infrastructure; } \\
\text { The socio-economics of the civil engineering } \\
\text { profession. }\end{array}$ \\
\hline $\begin{array}{l}\text { Civil engineering } \\
\text { context }\end{array}$ & “6 & 6 & “" & $\begin{array}{l}\text { Program/Project management- CEs must plan } \\
\text { and execute complex civil engineering projects. }\end{array}$ \\
\hline $\begin{array}{l}\text { Probability and } \\
\text { uncertainty }\end{array}$ & “6 & "6 & 6" & $\begin{array}{l}\text { The analysis of civil engineering projects to } \\
\text { safeguard the health, safety, and welfare of the } \\
\text { public. }\end{array}$ \\
\hline $\begin{array}{l}\text { Cost classification } \\
\text { and taxonomies }\end{array}$ & \multicolumn{3}{|c|}{$\begin{array}{l}\text { US Dept. of Labor. } \\
\text { 2016. "Engineering } \\
\text { competency model." }\end{array}$} & $\begin{array}{l}\text { Overhead, profit, direct and indirect labor, cost, } \\
\text { revenue, fundamentals of accounting }\end{array}$ \\
\hline Costing methods & 66 & 66 & 6 & $\begin{array}{l}\text { Contracts, costing approaches, fee structures, } \\
\text { cost, and pricing of projects and services. }\end{array}$ \\
\hline Standarc & “6 & 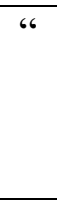 & “6 & $\begin{array}{l}\text { Prepare detailed cost estimates of capital and } \\
\text { annual operating costs, maintenance } \\
\text { and repair and replacement costs for a project } \\
\text { or component of a project. }\end{array}$ \\
\hline Varianc & 66 & 66 & "6 & $\begin{array}{l}\text { Prepare analyses of contractor requests for } \\
\text { additional compensation/change orders/claims. }\end{array}$ \\
\hline $\begin{array}{l}\text { Real and nominal } \\
\text { value }\end{array}$ & 6 & “6 & “6 & $\begin{array}{l}\text { Calculate projected inflation rates, determine } \\
\text { the effective inflation rate, base year, and year } \\
\text { of expenditure accounting. }\end{array}$ \\
\hline Break-e & “6 & “6 & “6 & $\begin{array}{l}\text { Estimate break-even points for construction } \\
\text { contract volume and overheads. }\end{array}$ \\
\hline $\begin{array}{l}\text { Experience curves } \\
\text { model }\end{array}$ & 6 & “6 & “6 & $\begin{array}{l}\text { Apply past cost experience to contract costing } \\
\text { where volume and sequencing are different; } \\
\text { analyzing construction delay claims. }\end{array}$ \\
\hline $\begin{array}{l}\text { Power factor } \\
\text { modeling }\end{array}$ & & & “6 & $\begin{array}{l}\text { Apply past cost experience to estimating } \\
\text { project costs with fixed and variable costs and } \\
\text { technology differences. }\end{array}$ \\
\hline $\begin{array}{l}\text { Relevant costing; } \\
\text { Economic } \\
\text { equivalence and } \\
\text { time value of } \\
\text { money }\end{array}$ & $\begin{array}{l}\text {-Civil E } \\
\text { of Know } \\
\text { (CEBoK } \\
\text {-US Dep } \\
\text { 2016. " } \\
\text { compete }\end{array}$ & & & $\begin{array}{l}\text { Sunk costs and project scoping. } \\
\text { Estimate initial and life-cycle costs of a project } \\
\text { and assess the impact of that cost and the } \\
\text { benefits on users of a project. }\end{array}$ \\
\hline
\end{tabular}




\section{Low Stakes Assessment Approach to Engineering Economy Instruction using revised Bloom Taxonomy}

\section{Procedural Knowledge Topics}

The course covers the following topic areas:

\begin{tabular}{|l|l|l|}
\hline \multicolumn{1}{|c|}{ Module } & \multicolumn{1}{|c|}{ Source } & \multicolumn{1}{c|}{ Content } \\
\hline $\begin{array}{l}\text { Civil engineering } \\
\text { context }\end{array}$ & $\begin{array}{l}\text { ABET Student learning } \\
\text { outcomes-SO2(Project } \\
\text { delivery context) }\end{array}$ & $\begin{array}{l}\text { Calculate project duration, costs, and cash flow } \\
\text { using project phasing. }\end{array}$ \\
\hline $\begin{array}{l}\text { Spreadsheet } \\
\text { applications }\end{array}$ & $\begin{array}{l}\text { ABET Student learning } \\
\text { outcomes-SO1(Modern } \\
\text { engineering tools) }\end{array}$ & $\begin{array}{l}\text { Developing templates to solve various } \\
\text { problems in Engineering Economics. }\end{array}$ \\
\hline $\begin{array}{l}\text { Probability and } \\
\text { uncertainty }\end{array}$ & $\begin{array}{l}\text {-Civil Engineering Body } \\
\text { of Knowledge, 3 } \\
\text { (CEBoK3) } \\
\text {-US Dept. of Labor. } \\
\text { 2016. "Engineering } \\
\text { competency model." }\end{array}$ & $\begin{array}{l}\text { Use of expected value and non-distributional } \\
\text { methods (triangle, rectangular, and binary) to } \\
\text { solve complex problems in Engineering } \\
\text { Economics. }\end{array}$ \\
\hline
\end{tabular}

\section{Assessment}

There are three grading elements in the course: ten weekly assignments, twenty-five class quizzes, and twelve weekly journal submissions for 47 student deliverables for the semester. The content of the quizzes and assignments is discussed below in the rationale and lesson learned. There were no mid-terms or finals for the course. The total points for all work are 3,000. Each one of the student deliverables ranges from a minimum of $1.66 \%$ to $3.33 \%$ of the student's grade. In the three years this approach has been used; there have been no motivational issues with the students in completing this work. All assessment work and grading is done online. The quizzes and assignments offer multiple attempts with scoring based upon the highest attempt or average as appropriate for the class's material and progression. Assessment work towards the end of the semester does not offer multiple attempts and is graded either by the first attempt or the average of all graded attempts. Practice sets were available, but these were limited to lower-level Bloom taxonomy cognitive rigor levels, as discussed below. Previously, course assessment consisted of high-stakes measures that were largely summative in nature, such as mid-terms and a comprehensive final. The assessment measure value ranged from $25 \%$ to $50 \%$. This paper defines high-stakes assessment as an assessment measure that is almost exclusively summative and constitutes $25 \%$ or more of the student's grade input. With the change in instructors, the objective was to introduce more formative content into the assessment. This was accomplished by reconstituting the high-stakes assessments into smaller, more manageable chunks that carried less weight or low-stakes. [8] This paper defines low-stakes assessments as those containing both formative and summative content and range from $1.5 \%$ to $5 \%$ of the student's grade. The primary benefit of low-stakes assessment is that "... students learn and recall information better with frequent opportunities to recall and apply the new knowledge.” [8] [9] 


\section{Low Stakes Assessment Approach to Engineering Economy Instruction using revised Bloom Taxonomy}

\section{Rationale}

The course uses criterion-based assessments based upon the Revised Bloom taxonomy (1956, revised 2001).[1] In its body of knowledge, the American Society of Civil Engineers, or CEBOK3, used the 1956 version of Bloom's taxonomy. The CEBOK3 authors argued that the original taxonomy's cognitive domain provided the necessary framework for assessing the "... recognition of knowledge and progressive development of intellectual abilities...." in civil engineering students.[2] Although the CEBOK3 authors chose to remain with the 1956 Bloom taxonomy, this paper recommends using the Anderson 2001 revision for the reasons to be discussed below. The taxonomy as revised in 2001 is organized as follows: [1]

- The first level of cognitive rigor or remember tests the student's ability to select a definition.

- The second level tests the student's ability to recall, interpret or explain the material.

- The third level assesses the student's ability to apply procedures to solve problems or Apply. It consists of two cognitive processes, namely "executing-when the task is an exercise (familiar)-and implementing-when the task is a problem (unfamiliar)." The main characteristic of the latter process is the no single answer aspect of it. In ABET accreditation terms [ABET, EAC, 2019 C3-C5 FAQs], the "open-ended" nature of this type of problemsolving makes it complex.

- The fourth level assesses the student's ability to differentiate or organize materials by breaking them down into "... constituent parts and determining how the parts are related to one another and ... an overall structure “. [3] Differentiating can be used to develop problems where the student is tasked with choosing relevant data or information in the presence of extraneous material from a word problem to use as inputs for a mathematical model. This assessment can be done with or without the use of an algorithmically calculated question.

- The fifth level assesses the student's ability to Organizing can be used to present the student with assessment questions that require manipulation of mathematical formulae or adjustment of problem parameters or constants.

Multiple-choice questions can measure "... some elements of in-depth understanding ... but not the higher Bloom levels of application or analysis. [4] Multiple-choice questions do not challenge a student to follow "... a chain of reasoning through several logical steps." [4] Algorithmic calculated questions (ACQs), on the other hand, meet this requirement and offer instructors a broad range of possibilities for Bloom 3 (Application), Bloom 4 (Analyze), and Bloom 5 (Evaluate) assessments using ACQs. It should be noted that assessment in the precalculator period (prior to 1980) was typically three to five questions in a test that was effectively a Bloom level 4 (analyze) in difficulty. If answered fully and correctly, the questions were indicative of an " $\mathrm{A}$ " in the grading schema. Less than fully correct answers determined the amount of partial credit for often the full range of lower grades (B, C, D, and F). With the advent of learning management systems (LMSs) and initiatives such as the ASCE civil engineering body of knowledge and the Bloom taxonomy, the situation changed. It is easier to construct separate questions of varying difficulty graded by the LMS versus manually grading a problem 


\section{Low Stakes Assessment Approach to Engineering Economy Instruction using revised Bloom Taxonomy}

to determine partial credit. Therefore, this discussion's framework assumes that partial credit is only used for a minor range of adjustments. This is typically $25 \%$ or less of the question value paired to a tolerance of $+/-10 \%$ of the correct answer. This approach requires a greater number of questions to be developed using the Bloom/Anderson taxonomy as a "ladder." This is well within the LMS capability to deliver quiz question sets with the appropriate mix of assessment components, including ACQs. The question is how to structure the question delivery?

LMS functionality allows the full range of these benefits when the modules are populated from question pools. The fundamental choice the Instructor must make is whether to construct assessments with randomly constructed question sets or tiered question sets that represent the increasing difficulty in terms of Bloom/Anderson cognitive rigor [1]. Subsidiary questions are whether the Instructor allows the student to scroll forward and come back to questions they have skipped over.

- The first alternative is attractive to instructors because it presents students with a completely randomized set of cognitive rigor questions, especially with remote or online assessments. Students already perceive assessments as obstacles, not as a learning experience, so the frustration level with this testing type is high. [6]

- The second alternative is to offer the student a pathway through the assessment (or scaffolding), working from the lower cognitive levels of remembering through understanding to apply and finally analyze. [1] Students develop confidence working through the true/false and multiple-choice components for the first two levels and then solve simplistic formula problems for level three. For level four, the student must manipulate the model and determine relevant information from irrelevant to solve the problem. This approach creates a sense of predictability in the student's mind as they know the overall test schema and expect each question to be more challenging. This course shifted from the former to the latter approach, and students have expressed more satisfaction and less frustration with this method in their weekly journals.

\section{Lessons Learned- Mapping the revised taxonomy to the course grading structure}

Using the revised taxonomy in designing the course grading structure requires independent estimates of students' cognitive levels before, during, and after the lecture.[5] Masapanta-Carrión recommends accomplishing this with independent estimates of the distribution of correct answers for the assessment. One critical point enabled the solution. Education is concerned with some degree of abstraction, generalization, or transfer. [6] In practical terms, this meant the student has the ability to transfer learning from known circumstances to solve an unknown problem. The revised taxonomy at level three, or Apply, has two sub-processes, executing and implementing. [1] The first is a familiar task performed in a familiar context, and the latter in a previously unknown task or context. This difference is analogous to students learning to solve closed-end problems in a familiar context and then progressing to unfamiliar, open-ended problems. The course objective, in many ways, is for the student to demonstrate the capacity to solve many types of engineering economic problems that are unfamiliar and complex. 


\section{Low Stakes Assessment Approach to Engineering Economy Instruction using revised Bloom Taxonomy}

Using this typing in the revised taxonomy within Apply (Execute versus Implement) provided a reliable predictor of performance for this course for the " $\mathrm{C}$ " and " $\mathrm{B}$ " blocks in the grading structure. Similarly, the taxonomy drew a difference between sorting out irrelevant information ("distractors") or Analyze and reconciling contradictory/incomplete information in Evaluate. The latter (Evaluate) being a higher level of cognitive rigor in the taxonomy or " $\mathrm{A}$ " block material than the Analyze material being the "B" block material. These were also reliable predictors of student performance for this course.

Based on the Instructor's experience using the revised taxonomy in practice for such applications as the CEBOK3 and teaching engineering economics, the following distribution of difficulty estimate was used for the class assessments in 2018 thru the 2021 period.

- $\quad 90 \%$ of the class should correctly answer the "D" block consisting of Remember level questions.

- $70 \%$ (roughly $60-80 \%$ ) of the class should correctly answer the "C" block consisting of Understand level and Apply/execute (3a) questions.

- $50 \%$ (roughly $40-60 \%$ ) of the class should correctly answer the "B" block consisting of Apply/implement (3b) and Analyze questions.

- $30 \%$ (roughly $20-40 \%$ ) of the class should correctly answer the "A" block consisting of Evaluate questions.

\section{Lessons Learned- The taxonomy as a cumulative hierarchy versus judged complexity} The original taxonomy [1] was viewed as a linear, cumulative hierarchy where the cognitive rigor categories were presumed not to overlap. The Revised Taxonomy allows categories to overlap on a scale of "judged complexity." [1] This difference is significant because often, there are higher rigor abilities in Bloom categories that are not thought of in that way. Retrieve and recall are ordinarily visualized as rote learning and fully capable of being answered solely from memory and thus rated a "D" block question. However, as the class developed, students were confronted with multiple choice questions and problems that required them to locate information in a large pool of candidate sources. This requirement involved constructing and using Boolean queries, including restricting queries to a specific site or excluding certain terms. This level of rigor is not understanding or comprehending, but a more complex process of retrieving information, inconceivable at the time of the first taxonomy but now prevalent in the $21^{\text {st }}$ century. Boolean queries are not the ordinary cognitive rigor question that can be answered from memory. These types of questions proved in multiple assessments to be reliable predictors of student performance for this course.

\section{Lessons Learned- The taxonomy as a tool for scaffolding between Understand and Apply}

Understand and Comprehend are viewed as more rigorous than Retrieve and recall in the revised taxonomy. Problem-solving using procedural knowledge, in turn, is viewed as more rigorous than Understand. The class uses a problem-based approach to instruction and relies heavily on using spreadsheets as the primary engineering tool to solve complex problems in engineering economy. Problems are complex and open-ended, capable of several interpretations, and require 


\section{Low Stakes Assessment Approach to Engineering Economy Instruction using revised Bloom Taxonomy}

the student to sort thru relevant and irrelevant, and sometimes conflicting information. This combination presents challenges to engineering students who are not exposed to much on the way of excel work in other classes after the first year. These students typically have acquired years of experience solving problems with calculators and place little value in learning to use Excel to solve problems. They also encounter significant difficulty converting complex word problems to the appropriate mathematical models and identifying relevant variables and constants. The students have trouble consistently solving multiple-step problems. They get it right one week and then wrong the next with no ability to review their answers; unable to reconstruct their logic, they become very frustrated with the coursework.

The solution to this problem was the creation of a separate module solely focused on building problem-solving "templates" using Microsoft Excel in a highly structured format that standardized the process in four parts: problem statement $(\mathrm{P})$, variables, constants, data (D) calculation (C), and answers (A). This was labeled the P-D-C-A approach.

Another effort focused on the student's ability to schematize the information or problem. It consisted of identifying variable relationships, constants, and logic tests in information and reducing them to algebraic expressions to carry out procedures using developed models and algebraic expressions. The Instructor has started developing schematic sets for all subject areas. It also proved in multiple assessments to be a reliable " $\mathrm{B}$ " block problem. The students have also expressed more satisfaction and less frustration with this method in their weekly journals.

\section{Lessons Learned- Flipped classroom delivery and assessment}

Effective use of the "flipped classroom" delivery method also requires combining formative and summative assessment elements in assessment measures. The full functionality of the LMS technology again is used to manage both aspects of this challenge. The course schedule and work plans control the introduction of material and drive the structure of the measures. Again, the Revised Taxonomy played a key part in the design.

1. The pre-work practice assessments are solely focused on the current week's subject. All "D" and "C" block questions offer complete answers on the feedback responses. Practice sets have some Bloom "B" block and no "A" block materials.

2. After their first introduction as an assessment measure, the dominant focus of the " $\mathrm{D}$ " and "C" blocks is diagnostic or "formative" in nature. The purpose is to work on why these learning outcomes are still encountering problems. Why are they not meeting the attainment of learning targets? Is the wording poor, etc. ? Portions of the " $\mathrm{C}$ " and " $\mathrm{B}$ " blocks are dedicated to repeating questions from the pool until the class hits the targeted attainment level.

The following table is a schematic approach to how the weeks and assessment materials were deployed. 


\section{Low Stakes Assessment Approach to Engineering Economy Instruction using revised Bloom Taxonomy}

Assessment in the Flipped Classroom using Revised Bloom Taxonomy as reference (Three week example)

\begin{tabular}{|c|c|c|c|c|c|c|c|c|}
\hline & \multicolumn{4}{|c|}{ Week I } & \multicolumn{2}{|c|}{ Week II } & \multicolumn{2}{|c|}{ Week III } \\
\hline & $\begin{array}{l}\text { Pre-class } \\
\text { work }\end{array}$ & \begin{tabular}{|l|} 
Pre-class \\
Assessment \\
I
\end{tabular} & $\begin{array}{l}\text { Post Class } \\
\text { Assessment } \\
\text { II }\end{array}$ & $\begin{array}{l}\text { Post Class } \\
\text { Assessment III }\end{array}$ & $\begin{array}{l}\text { Post Class } \\
\text { Assessment } \\
\text { IV }\end{array}$ & $\begin{array}{l}\text { Post Class } \\
\text { Assessment V }\end{array}$ & $\begin{array}{l}\text { Post Class } \\
\text { Assessment } \\
\text { VI }\end{array}$ & $\begin{array}{l}\text { Post Class } \\
\text { Assessment } \\
\text { VII }\end{array}$ \\
\hline $\begin{array}{l}\text { Type of } \\
\text { Assessment }\end{array}$ & $\begin{array}{l}\text { Practice } \\
\text { quiz }\end{array}$ & $\begin{array}{l}\text { Quiz I- } \\
50 \text { points }\end{array}$ & $\begin{array}{l}\text { Quiz II- } \\
50 \text { points }\end{array}$ & $\begin{array}{l}\text { Assignment I - } \\
100 \text { points }\end{array}$ & $\begin{array}{l}\text { Quiz III and } \\
\text { IV- } 50 \text { pts }\end{array}$ & $\begin{array}{l}\text { Assignment II- } \\
-100 \text { points }\end{array}$ & $\begin{array}{l}\text { Quiz V and } \\
\text { VI-50 pts }\end{array}$ & $\begin{array}{l}\text { Assignment } \\
\text { III- } 100 \text { pts }\end{array}$ \\
\hline Total \# of qs & 5-7 total & 11 total & 11 total & 18 total & 11 total & 18 total & 11 total & 18 total \\
\hline & 3-4 ques & $6-7$ & $6-7$ & 7-9 questions & $6-7$ & 7-9 questions & $6-7$ & 7-9 questions \\
\hline $\begin{array}{l}\text { "D" and } \\
\text { "C" grade } \\
\text { performance }\end{array}$ & $\begin{array}{l}\text { The pre- } \\
\text { work } \\
\text { practice } \\
\text { assessments } \\
\text { are solely } \\
\text { focused on } \\
\text { the current } \\
\text { week's } \\
\text { subject. } \\
\text { All "D" and } \\
\text { "C" block } \\
\text { questions } \\
\text { offer full } \\
\text { feedback } \\
\text { responses. }\end{array}$ & $\begin{array}{l}\text { The pre- } \\
\text { class } \\
\text { assessments } \\
\text { are focused } \\
\text { on the } \\
\text { current } \\
\text { week's } \\
\text { subject. } \\
\text { All "D" and } \\
\text { "C" block } \\
\text { questions } \\
\text { offer full } \\
\text { feedback } \\
\text { responses. }\end{array}$ & $\begin{array}{l}\text { These } \\
\text { assessments } \\
\text { are focused } \\
\text { on the } \\
\text { current week } \\
\text { subject with } \\
\text { a mix of } \\
\text { previous one } \\
\text { or two } \\
\text { workshops } \\
\text { that the } \\
\text { LMS } \\
\text { identifies as } \\
\text { needing } \\
\text { more work. }\end{array}$ & $\begin{array}{l}\text { The dominant } \\
\text { focus of the } \\
\text { "D" and "C" } \\
\text { blocks in the } \\
\text { assignments is } \\
\text { diagnostic. The } \\
\text { purpose is to } \\
\text { work on why } \\
\text { these learning } \\
\text { outcomes are } \\
\text { still } \\
\text { encountering } \\
\text { problems. Is } \\
\text { the wording } \\
\text { poor, etc.? }\end{array}$ & $\begin{array}{l}\text { The pre-class } \\
\text { assessments } \\
\text { are focused on } \\
\text { the current } \\
\text { week's } \\
\text { subject. The } \\
\text { second quiz is } \\
\text { a mix of } \\
\text { previous one } \\
\text { or two } \\
\text { workshops } \\
\text { needing more } \\
\text { work. }\end{array}$ & $\begin{array}{l}\text { The dominant } \\
\text { focus of the } \\
\text { " } \mathrm{D} \text { " and " } C \text { " } \\
\text { blocks in the } \\
\text { assignments is } \\
\text { diagnostic. } \\
\text { The purpose is } \\
\text { to work on } \\
\text { why these } \\
\text { learning } \\
\text { outcomes are } \\
\text { still } \\
\text { encountering } \\
\text { problems. Is } \\
\text { the wording } \\
\text { poor, etc.? }\end{array}$ & $\begin{array}{l}\text { The pre- } \\
\text { class } \\
\text { assessments } \\
\text { are focused } \\
\text { on the } \\
\text { current } \\
\text { week's } \\
\text { subject. The } \\
\text { second quiz } \\
\text { is a mix of } \\
\text { previous one } \\
\text { or two } \\
\text { workshops } \\
\text { needing } \\
\text { more work. }\end{array}$ & $\begin{array}{l}\text { The dominant } \\
\text { focus of the } \\
\text { "D" and "C" } \\
\text { blocks in these } \\
\text { assignments is } \\
\text { diagnostic. } \\
\text { The purpose is } \\
\text { to work on } \\
\text { why these } \\
\text { learning } \\
\text { outcomes are } \\
\text { still } \\
\text { encountering } \\
\text { problems. Is } \\
\text { the wording } \\
\text { poor, etc.? }\end{array}$ \\
\hline
\end{tabular}




\section{Low Stakes Assessment Approach to Engineering Economy Instruction using revised Bloom Taxonomy}

\begin{tabular}{|c|c|c|c|c|c|c|c|c|}
\hline & \multicolumn{4}{|c|}{ Week I } & \multicolumn{2}{|c|}{ Week II } & \multicolumn{2}{|c|}{ Week III } \\
\hline $\begin{array}{l}\text { Type of } \\
\text { Assessment }\end{array}$ & $\begin{array}{l}\text { Practice } \\
\text { quiz }\end{array}$ & $\begin{array}{l}\text { Quiz I- } \\
50 \text { points }\end{array}$ & $\begin{array}{l}\text { Quiz II- } \\
50 \text { points }\end{array}$ & $\begin{array}{l}\text { Assignment I - } \\
100 \text { points }\end{array}$ & $\begin{array}{l}\text { Quiz III and } \\
\text { IV- } 50 \text { pts }\end{array}$ & $\begin{array}{l}\text { Assignment II- } \\
-100 \text { points }\end{array}$ & $\begin{array}{l}\text { Quiz V and } \\
\text { VI-50 pts }\end{array}$ & $\begin{array}{l}\text { Assignment } \\
\text { III- } 100 \text { pts }\end{array}$ \\
\hline & $\begin{array}{l}0-2 \\
\text { questions }\end{array}$ & $\begin{array}{l}\text { 2-3 } \\
\text { questions }\end{array}$ & $\begin{array}{l}2-3 \\
\text { questions }\end{array}$ & 2-3 questions & 2-3 questions & 2-3 questions & $\begin{array}{l}\text { 2-3 } \\
\text { questions }\end{array}$ & 2-3 questions \\
\hline $\begin{array}{l}\text { "B" grade } \\
\text { performance } \\
\text { (All "B" } \\
\text { blocks will } \\
\text { include } \\
\text { previous } \\
\text { weeks } \\
\text { material } \\
\text { that the } \\
\text { LMS } \\
\text { identifies as } \\
\text { problematic- } \\
\text { as space } \\
\text { allows) }\end{array}$ & $\begin{array}{l}\text { The pre- } \\
\text { work } \\
\text { practice } \\
\text { assessments } \\
\text { are solely } \\
\text { focused on } \\
\text { the current } \\
\text { week's } \\
\text { subject. } \\
\text { Limited to } \\
\text { no } \\
\text { feedback } \\
\text { on "B" } \\
\text { questions }\end{array}$ & $\begin{array}{l}\text { Quiz I- This } \\
\text { block } \\
\text { repeats a B } \\
\text { block } \\
\text { assessment } \\
\text { from } \\
\text { previous } \\
\text { week and } \\
\text { diagnostic } \\
\text { problems } \\
\text { suggested } \\
\text { by LMS. }\end{array}$ & $\begin{array}{l}\text { Quiz II- } \\
\text { Introduces } \\
\text { first "B" } \\
\text { block } \\
\text { question } \\
\text { from Week I } \\
\text { lectures. }\end{array}$ & $\begin{array}{l}\text { Primary } \\
\text { emphasis is on } \\
\text { current week } \\
\text { with mix of } \\
\text { LMS identified } \\
\text { problems with } \\
\text { difficulty or } \\
\text { discrimination. }\end{array}$ & $\begin{array}{l}\text { Quiz III } \\
\text { repeats a B } \\
\text { block } \\
\text { assessment } \\
\text { from Week I } \\
\text { and diagnostic } \\
\text { problems } \\
\text { suggested by } \\
\text { LMS. } \\
\text { Quiz VI- } \\
\text { introduces } \\
\text { first "B" } \\
\text { question from } \\
\text { Week II. }\end{array}$ & $\begin{array}{l}\text { Primary } \\
\text { emphasis is on } \\
\text { current week } \\
\text { with mix of } \\
\text { Bb identified } \\
\text { problems with } \\
\text { difficulty or } \\
\text { discrimination. } \\
0-2 \text { essay } \\
\text { response on } \\
\text { approach to a } \\
\text { "B" question } \\
\text { AND/OR a } \\
\text { template } \\
\text { submittal }\end{array}$ & $\begin{array}{l}\text { Quiz V- } \\
\text { repeats a B } \\
\text { block } \\
\text { assessment } \\
\text { from Week } \\
\text { II and } \\
\text { diagnostic } \\
\text { problems } \\
\text { suggested by } \\
\text { LMS. } \\
\text { Quiz VI- } \\
\text { introduces } \\
\text { first "B” } \\
\text { question } \\
\text { from Week } \\
\text { III. }\end{array}$ & $\begin{array}{l}\text { Primary } \\
\text { emphasis is on } \\
\text { current week } \\
\text { with mix of } \\
\text { Bb identified } \\
\text { problems with } \\
\text { difficulty or } \\
\text { discrimination. } \\
0 \text {-2 essay } \\
\text { response on } \\
\text { approach to a } \\
\text { "B" question } \\
\text { AND/OR a } \\
\text { template } \\
\text { submittal. }\end{array}$ \\
\hline
\end{tabular}




\section{Low Stakes Assessment Approach to Engineering Economy Instruction using revised Bloom Taxonomy}

\begin{tabular}{|c|c|c|c|c|c|c|c|c|}
\hline & \multicolumn{4}{|c|}{ Week I } & \multicolumn{2}{|c|}{ Week II } & \multicolumn{2}{|c|}{ Week III } \\
\hline $\begin{array}{l}\text { Type of } \\
\text { Assessment }\end{array}$ & $\begin{array}{l}\text { Practice } \\
\text { quiz }\end{array}$ & $\begin{array}{l}\text { Quiz I- } \\
50 \text { points }\end{array}$ & $\begin{array}{l}\text { Quiz II- } \\
50 \text { points }\end{array}$ & $\begin{array}{l}\text { Assignment I - } \\
100 \text { points }\end{array}$ & $\begin{array}{l}\text { Quiz III and } \\
\text { IV- } \\
50 \text { points each }\end{array}$ & $\begin{array}{l}\text { Assignment II- } \\
-100 \text { points }\end{array}$ & $\begin{array}{l}\text { Quiz III and } \\
\text { IV- } \\
50 \text { points } \\
\text { each }\end{array}$ & $\begin{array}{l}\text { Assignment } \\
\text { III- } \\
100 \text { points }\end{array}$ \\
\hline & None & $\begin{array}{l}1-2 \\
\text { questions }\end{array}$ & $\begin{array}{l}1-2 \\
\text { questions }\end{array}$ & 1-2 questions & 1-2 questions & 1-2 questions & $\begin{array}{l}\text { 1-2 } \\
\text { questions }\end{array}$ & 1-2 questions \\
\hline $\begin{array}{l}\text { "A" grade } \\
\text { performance }\end{array}$ & $\begin{array}{l}\text { No } \\
\text { feedback } \\
\text { on A Block } \\
\text { questions. }\end{array}$ & $\begin{array}{l}\text { Repeats } \\
\text { previous } \\
\text { week's A } \\
\text { block } \\
\text { question. }\end{array}$ & \begin{tabular}{|l} 
Repeats \\
previous A \\
block \\
questions \\
based upon \\
diagnostics.
\end{tabular} & $\begin{array}{l}\text { Introduces first } \\
\text { "A" block } \\
\text { question from } \\
\text { Week I lectures }\end{array}$ & $\begin{array}{l}\text { Repeats A } \\
\text { block } \\
\text { questions } \\
\text { from Week I } \\
\text { lectures and } \\
\text { based upon } \\
\text { LMS } \\
\text { diagnostics. }\end{array}$ & $\begin{array}{l}\text { This block } \\
\text { introduces first } \\
\text { "A" question } \\
\text { from Week II } \\
\text { lectures }\end{array}$ & $\begin{array}{l}\text { Repeats A } \\
\text { block } \\
\text { questions } \\
\text { from Week } \\
\text { II lectures } \\
\text { and based } \\
\text { upon LMS } \\
\text { diagnostics. }\end{array}$ & $\begin{array}{l}\text { This block } \\
\text { introduces first } \\
\text { "A" question } \\
\text { from Week III } \\
\text { lectures }\end{array}$ \\
\hline
\end{tabular}

The following table gives an illustration of the LMS assessment analysis test analysis. 


\section{Low Stakes Assessment Approach to Engineering Economy Instruction using revised Bloom Taxonomy}

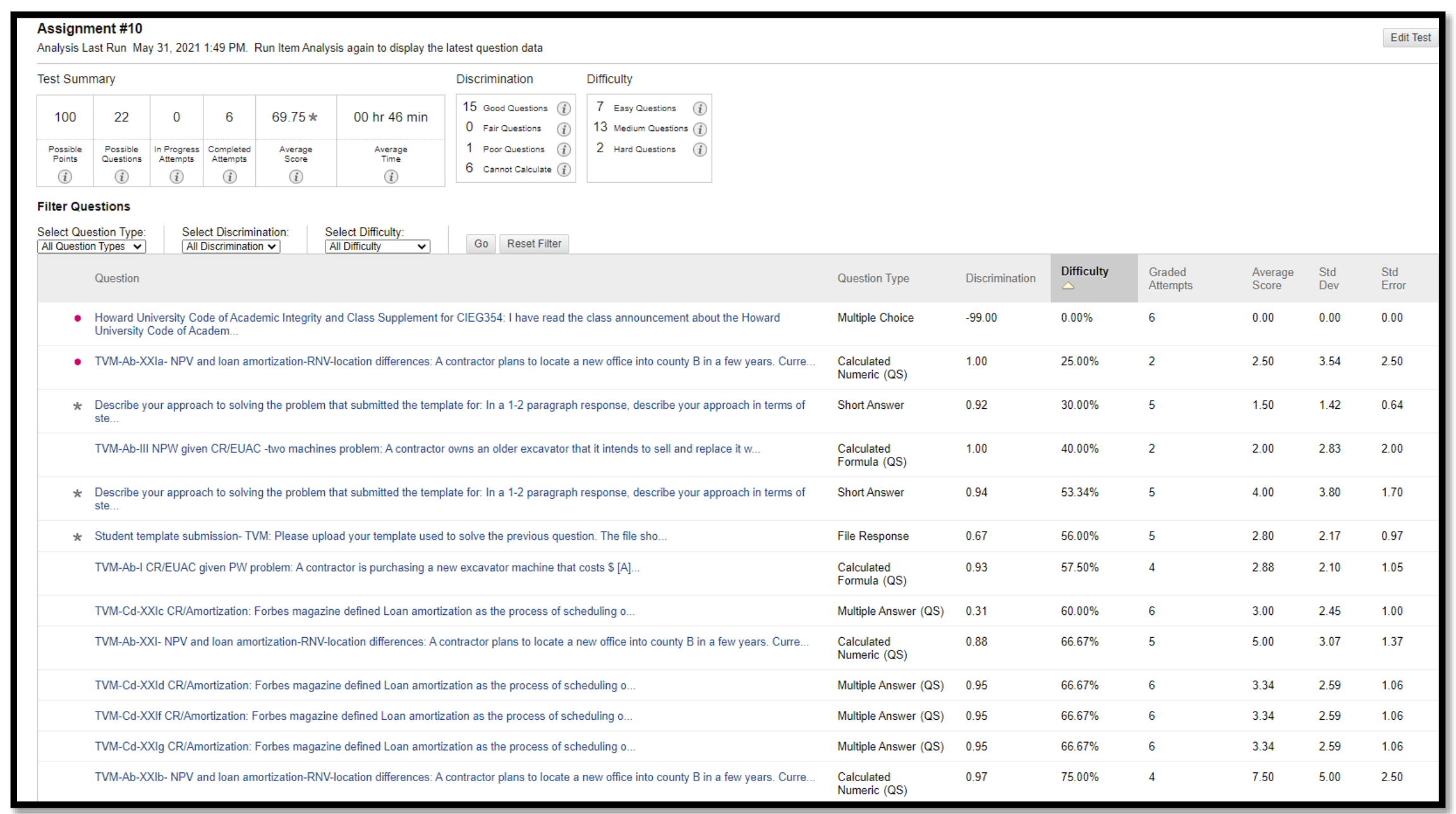

This figure is an example of how the LMS evaluates assessments for discrimination and difficulty. This serves as the basis for the Instructor developing the diagnostic blocks for the individual assessments. 


\section{Low Stakes Assessment Approach to Engineering Economy Instruction using revised Bloom Taxonomy}

The latter figure is ranked by the LMS for difficulty. Questions are labeled by unit and ranked with the grade structure using the Revised Taxonomy. [1] In this example, the second question is coded as "TVM-Ab-XXIa- NPV ...RNV". This means that it is a time value of money (TVM) question with Net present value (NPV) and inflation (RNV), and location cost adjustment components. The expectation is that as the class sees this question multiple times, even if with different parameters, it degrades from an "A" block to a "B" block question as the students become more familiar with solving this type of problem. TVM-Ab-XXIa had a $25 \%$ difficulty as expected and was used for the first time in this assessment, as was TVM-Ab-III NPW with 40\%. Three other questions were used as diagnostics multiple times and achieved a lower level of difficulty, such as TVM-Ab-I CR/EUAC (Capital recovery), TVM-Ab-XXI- NPV, and TVMAb-XXIb- NPV.

Another example is the question "TVM-Cd-XXIc CR/Amortization," which scored only $60 \%$ in difficulty versus the target of $70 \%$. This question was reviewed for clarity and revised to improve its performance on first exposure to the students.

Lastly, the Roman numbering is solely for tracking the number of different questions in this pool.

\section{Conclusion}

Entwistle wrote that the "... single, strongest influence on learning is ... assessment ... even the form of an examination question or essay topics set can affect how students study." [7] The author's experience using the revised taxonomy combined with the technology embedded into LMS affirms that statement. 


\section{Low Stakes Assessment Approach to Engineering Economy Instruction using revised Bloom Taxonomy}

\section{References}

[1] L. W. Anderson, and B. S. Bloom. "A taxonomy for learning, teaching, and assessing: A revision of Bloom's taxonomy of educational objectives.” Longman, 2001.

[2] American Society of Civil Engineers. "Civil engineering body of knowledge for the 21 st century: Preparing the civil engineer for the future." [Online] American Society of Civil Engineers, 2019.

[3] K. Whalen, “The Reflective Learning Framework: A guide for students and educators." (2018). [Online] https://asp.mcmaster.ca/wp-content/uploads/2018/10/The-ReflectiveLearning-Framework-08.2018.pdf

[4] S. Buckles, Stephen, and J. J. Siegfried. "Using multiple-choice questions to evaluate indepth learning of economics." The Journal of Economic Education 37, no. 1 (2006): 4857.

[5] S. Masapanta-Carrión, \& J. Velázquez-Iturbide,. "A systematic review of the use of Bloom's taxonomy in Computer Science education." (2018, February) In Proceedings of the 49th acm technical symposium on computer science education (pp. 441-446).

[6] F. Fauziah, "The Analysis Of Authenticity In Summative Assessment In Avocational School In Bandung." (2019). Jurnal Sains Riset, 7(1). http://journal.unigha.ac.id/index.php/JSR/article/download/1/1

[7] N. Entwistle, "Recent research on student learning," in: J. TAIT \& P. KNIGHT (Eds) The Management of Independent Learning, (1996) pp. 97-112 (London, Kogan Page).

[8] C. Rohrbacher, and R. Pearson. "Quarantining High-Stakes Assessments in an Introductory Physics Class." [Online] Intersection: A Journal at the Intersection of Assessment and Learning 2.1 (2020): 17619. https://aalhe.scholasticahq.com/article/17619.pdf [Accessed in 2021.]

[9] H. Roediger III, "Applying cognitive psychology to education: Translational educational science." Psychological Science in the Public Interest 14.1 (2013): 1-3.

[10] J. C. Wood, and S. C. Pendleton. "Using problem-based learning to modify curriculum to meet industry needs." Proceedings of the 2002 American Society for Engineering Education Annual Conference \& Exposition (2002): [Online] https://peer.asee.org/usingproblem-based-learning-to-modify-curriculum.pdf [Accessed in 2021.] 


\section{Low Stakes Assessment Approach to Engineering Economy Instruction using revised Bloom Taxonomy}

[11] N. E. Basri, Ahmad, Shahrom Md Zain, Othman Jaafar, Hassan Basri, and Fatihah Suja. "Introduction to environmental engineering: a problem-based learning approach to enhance environmental awareness among civil engineering students." Procedia-Social and Behavioral Sciences 60 (2012): 36-41. [Online] http://ilin.asee.org/2013/index_files/hill.pdf [Accessed in 2021.]

[12] R. M. Marra, D. H. Jonassen, B. Palmer, and S. Luft. "Why problem-based learning works: Theoretical foundations." Journal on Excellence in College Teaching 25 (2014). [Online] http://www.lhthompson.com/uploads/4/2/1/1/42117203/problem-based_learning.pdf [Accessed in 2021.]

[13] J. Marks, and K. J. Ketchman. "Understanding the Benefits of the Flipped Classroom in the Context of Sustainable Engineering." Proceedings of the 2014 American Society for Engineering Education Annual Conference \& Exposition (2014).

[14] S. P. Gross, and E. S. Musselman. "Implementation of an inverted classroom in structural design courses." Journal of Professional Issues in Engineering Education and Practice 144, no. 3 (2018): 05018003.

[15] E. F. Gehringer, and B. W. Peddycord III. "Teaching strategies when students have access to solution manuals." Proceedings of the 2013 American Society for Engineering Education Annual Conference \& Exposition (2013): 1.

[16] T. Shepard, A. B. Hoxie, and M. Anderson. "I did not anticipate this: Experiences from the early years." In ASEE Annual Conference and Exposition, Conference Proceedings. (2014).

[17] American Society of Civil Engineers. "Civil engineering body of knowledge: Preparing the future civil engineer." American Society of Civil Engineers, (2019). [Online] https://www.asce.org/civil_engineering_body_of_knowledge/ [Accessed in 2021.]

[18] AAES (American Association of Engineering Societies) and the US Dept. of Labor. (2016). "Engineering competency model." [Online] https://www.careeronestop.org/competencymodel/competency-models/engineering.aspx [Accessed in 2021.]

[19] Leslie, "Engineering Competency Model” In ASEE Annual Conference and Exposition, Conference Proceedings. (2016).

[20] L. J.Everett, R. M. Alexander, and M. Wienen. "A grading method that promotes competency and values broadly talented students." Journal of Engineering Education 88, no. 4 (1999): 477-483. 


\section{Low Stakes Assessment Approach to Engineering Economy Instruction using revised Bloom Taxonomy}

[21] S. H., McIntyre and J. M. Munson. "Exploring cramming: Student behaviors, beliefs, and learning retention in the principles of marketing course." Journal of Marketing Education 30, no. 3 (2008): 226-243.

[22] D. Brockway and K. James. "Effect of Scaffolding in the Assessment of Engineering Practices for Middle School Students", Proceedings of the 2018 American Society for Engineering Education Annual Conference \& Exposition (2018): [Online] https://www.asee.org/public/conferences/106/papers/21875/view [Accessed in 2021.] 